\title{
PENYELENGGARAAN SERTIFIKASI TENAGA AHLI JASA KONSTRUKSI DI INDONESIA TAHUN 2000-2012
}

\author{
Irika Widiasanti
}

\begin{abstract}
Abstrak
Industri konstruksi merupakan industri yang mempunyai karakter yang, unik, banyak pihak yang terlibat dengan berbagai fungsi yang berbeda (Penyedia jasa konsultan, Penyedia jasa konstruksi, Suplier dan Owner). Bunga rampai ini berisi hasil-hasil penelitian terkait dengan penelitian tentangpenyelenggaraan sertifikasi tenaga ahli dalam kurun waktu $2005-2012$.
\end{abstract}

\begin{tabular}{|r|r|}
\hline Ir. Irika Widiasnti, MT \\
Staff Pengajar Jurusan Teknik Sipil \\
Fakultas Teknik \\
Universitas Negeri Jakarta, 13220 \\
email : irika@ymail.com
\end{tabular}

\section{PENDAHULUAN}

Sertifikasi terhadap tenaga ahli merupakan wujud tanggung jawab yang diemban oleh konsultan maupun perseorangan dalam hal proses jasa konstruksi. Jika terjadi kegagalan bangunan yang disebabkan karena kesalahan perencana atau pengawas konstruksi, dan hal tersebut terbukti menimbulkan kerugian bagi pihak lain, maka perencana atau pengawas konstruksi wajib bertanggung jawab sesuai dengan bidang profesi dan dikenakan ganti rugi (UU 18/1999 Pasal 26). Hal inilah yang mendasari pentingnya penerapan sertifikasi terhadap tanaga ahli yang dimiliki oleh Konsultan.

Pelaksanaan sertifikasi bagi para tenaga ahli maupun orang perseorangan yang berkaitan dengan profesi dan disiplin keilmuan yang dimiliki pada dasarnya sudah tersosialisasi 
dibeberapa asosiasi profesi, namun pada kenyataannya hanya sebagian kecil dari masyarakat jasa konstruksi yang merasakan pentingnya kepemilikan sertifikat keahlian tersebut.

Mengingat bahwa sertifikasi akan menunjukkan kompetensi SDM (Sumber daya Manusia) yang terlibat dalam proyek, maka sertifikasi merupakan syarat mutlak untuk menjamin mutu dan keamanan pengerjaan proyek di lapangan. Meskipun demikian, tenyata jumlah pemegang sertifikasi keahlian di Indonesia masih minim. Data IAI (Ikatan Arsitek Indonesia) yang mengeluarkan sertifikasi bagi keahlian tenaga ahli arsitek menunjukkan bahwa hanya $10 \%$ dari 10.000 anggotanya yang bersertifikat, itupun dengan komposisi jumlah kualifikasi pemegang sertifikat dari kelas pratama (menjalani profesi setelah 4 tahun lulus kuliah), kelas madya (lebih dari 4 tahun), dan kelas utama (tingkat keahliannya diakui setara arsitek asing) yang kurang proporsional. Data yang tercatat pada HAKI (Himpunan Ahli Konstruksi Indonesia) menunjukkan jumlah dan komposisi yang sedikit lebih baik. Dari 3586 orang anggota, hanya $20,65 \%$ yang bersertifikat dengan kualifikasi sebagai berikut : 11,21\% Profesional Muda, $6,44 \%$ Profesional Madya, dan 3\% Profesional Utama (Kompas Jatim, 18 Jan 2007).

Asosiasi Profesi yang telah terakreditasi oleh LPJK Nasional dapat melakukan sertifikasi yang meliputi klasifikasi dan kualifikasi kepada anggotanya, baik tenaga ahli maupun tenaga terampil.

Asosiasi Profesi merupakan satu atau lebih wadah organisasi dan atau himpunan orang perseorangan terampil dan atau ahli atas dasar kesamaan disiplin keilmuan dan atau profesi dibidang konstruksi atau yang berkaitan dengan jasa konstruksi.

Ahli adalah seseorang yang berlatar belakang pendidikan tinggi dan atau memiliki kemampuan serta mendalami dan menguasai penerapan pengetahuan, ilmu, teknologi, seni dan atau bidang-bidang tertentu. Didalam bidang jasa konstruksi tenaga ahli adalah tenaga dibidang jasa konstruksi yang memiliki sertifikat (SKA) bagi perencana konstruksi, pengawas konstruksi dan pelaksana konstruksi sebagai bukti kompetensi dan kemampuan profesi keahlian kerja orang perseorangan dibidang jasa konstruksi menurut disipli keilmuan dan/atau kefungsian dan/atau keahlian tertentu.

\section{PEMBAHASAN}

Observasi lapangan proses sertifikasi yang dilaksanakan oleh IAI Jawa Timur masih terus berjalan. Dari Jumlah anggota Aktif yang mencapai 525 orang hanya 78 anggota yang telah 
memiliki sertifikat profesional, hal ini menunjukkan hanya $14 \%$ dari jumlah tenaga Ahli yang aktif yang telah memiliki Sertifikat. Dari Total Anggota Profesional yang ada 3 orang memiliki kualifikasi Utama $(3,8 \%), 59$ orang kualifikasi Madya $(75,6 \%)$ dan 16 orang diantaranya kualifikasi Pratama (20,6\%).

Dalam Proses sertifikasi Tenaga Ahli di IAI Jawa Timur hampir 60\% Tenaga Ahli profesional melakukan perpanjangan sertifikasi dan $40 \%$ sisanya mengajukan sertifikasi baru. Selama Tahun 2008 proses pelaksanaan sertifikasi tenaga ahli di IAI menunjukkan grafik yang kurang signifikan. Hal ini ditunjukan dengan minimnya jumlah anggota baru yang mengajukan proses sertifikasi. (Rachmanto D. , 2009).

Pelaksanaan Sertifikasi Tenaga Ahli Arsitek di Surabaya yang dilaksanakan oleh IAI Daerah Jawa Timur telah dilaksanakan secara belum optimal dimana indikator yang menunjukkan bahwa tingkat partisipasi anggota untuk aktif dalam melaksanakan sertifikasi masih kurang. Dari observasi lapangan proses sertifikasi yang dilaksanakan oleh IAI Jawa Timur masih terus berjalan. Dari Jumlah anggota Aktif yang mencapai 525 orang hanya 78 anggota yang telah memiliki sertifikat profesional, hal ini menunjukkan hanya $14 \%$ dari jumlah tenaga Ahli yang aktif yang telah memiliki Sertifikat. Dari Total Anggota Profesional yang ada 3 orang memiliki kualifikasi Utama (3,8\%) , 59 orang kualifikasi Madya (75,6\%) dan 16 orang diantaranya kualifikasi Pratama (20,6\%). Dalam Proses sertifikasi Tenaga Ahli di IAI Jawa Timur hampir 60\% Tenaga Ahli profesional melakukan perpanjangan sertifikasi dan $40 \%$ sisanya mengajukan sertifikasi baru. Selama tahun 2008 proses pelaksanaan sertifikasi tenaga ahli di IAI menunjukkan grafik yang kurang signifikan.

2. Berdasarkan analisa Tingkat Persepsi dan kepentingan diketahui bahwa munculnya gap negatif menunjukkan tingkat kepentingan responden terhadap pelaksanaan sertifikasi tersebut lebih besar dibandingkan dengan persepsi responden. Nilai Gab terbesar -2.10 yang muncul adalah variabel PSTA9 (Registrasi Sertifikasi) oleh mayoritas responden menanggapi proses registrasi ini sebagai penentu dalam sertifikasi namun dalam penerapannya rata-rata tanggapan responden yang diperoleh sebesar 2.6 termasuk kategori tidak baik (TB) sehingga secara keseluruhan Proses sertifikasi tenaga ahli masih belum sepenuhnya mampu memenuhi kepentingan responden, walaupun secara kebijakan yang diterapkan oleh IAI telah disosialisaikan kepada anggota. Dari data yang ada masih banyak faktor-faktor yang memerlukan prioritas penanganan karena faktor-faktor tersebut dianggap sangat penting, 
namun tingkat pelaksanaannya masih belum memuaskan. Faktor faktor tersebut adalah (1) Informasi Pendaftaran, (2) Biaya Sertifikasi, (3) Metode dan Verifikasi Sertifikasi, (4) Revisi dokumen sertifikasi, (5) waktu kelulusan).

3. Berdasarkan analisi faktor-faktor strategis internal dan Eksternal dari pelaksanaan sertifikasi tenaga ahli arsitek oleh IAI di Surabaya. Posisi strategi yang digunakan adalah W - T (Weakness - Treath) meminimalkan kelemahan internal dan menghindari ancaman eksternal. Dengan mempertimbangkan hasil analisa persepsi dan kepentingan serta analisa kuadran, maka strategi yang sebaiknya diterapkan dalam pelaksanaan sertifikasi Tenaga Ahli di Surabaya adalah

a. Penyusunan rencana program pelaksanaan sertifikasi.

b. Mengusulkan penyusunan dan menetapkan peraturan perundangan yang mendukung penerapan sertifikasi Tenaga Ahli .

(Rachmanto D. , 2009)

Kegagalan bangunan dan kegagalan konstruksi dapat disebabkan oleh faktor teknis maupun faktor non teknis. Faktor teknis karena adanya penyimpangan proses pelaksanaan yang tidak memenuhi spesifikasi teknis yang disepakati dalam kontrak, sedangkan faktor non teknis lebih disebabkan karena tidak kompetennya Badan Usaha, tenaga kerja, tidak profesionalnya tata kelola manajerial antara pihak-pihak yang terlibat dalam proyek konstruksi. (Wiyana, 2012) Gambaran umum SDM konstruksi di lokasi proyek yang diteliti menunjukkan bahwa meskipun ada tenaga terampil dan sertifikat keahlian, kegagalan bangunan masih saja terjadi. (Wiyana, 2012)

Kegagalan Konstruksi dan kegagalan bangunan dipengaruhi secara struktural oleh variabel SBU sebesar 0.1181, variable SKT sebesar 0.0501, variabel SKA sebesar 0.0250. Artinya kompetensi SBU, SKA dan SKT berkontribusi terhadap Kegagalan Konstruksi dan Kegagalan Bangunan. (Wiyana, 2012)

Berdasarkan faktor-faktor penyebab keterlambatan pelaksanaan proyek, salah satu di antaranya faktor tenaga kerja. Dari faktor tenaga kerja, faktor yang paling mempengaruhi adalah faktor keahlian tenaga kerja (angka 1), kedisiplinan tenaga kerja (angka 2), jumlah pekerja yang kurang memadai/sesuai dengan aktivitas pekerjaan yang ada (angka 3), angka ketidakhadiran pekerja (angka 4), motivasi kerja para pekerja (angka 5), komunikasi antara tenaga kerja dan kepala tukang/mandor (angka 6), dan kesukuan/nasionalisme tenaga kerja (angka 7). (Widhiawati, 2009) 
Undang-undang dan penataan pranata kelembagaan yang merupakan salah satu faktor penting dalam sektor konstruksi perlu dikaji ulang dan dievaluasi. Sebagai contoh, UndangUndang Jasa Konstruksi Nomor 18 Tahun 1999 dimana memberikan porsi lebih besar kepada masyarakat untuk ikut aktif berpartisipasi dalam pengembangan usaha industri konstruksi. Salah satu implementasinya adalah asosiasi profesi merupakan badan yang berhak memberikan sertifikasi kepada anggotanya.

Pada kenyataannya di lapangan, konsekuensi dari aturan tersebut timbulnya persaingan antara lembaga-lembaga tersebut dalam rangka berebut kewenangan dan ekonomi dalam mengadakan sertifikasi. Terlihat dengan jelas bahwa masing-masing asosiasi-asosiasi tersebut dalam pelaksanaannya di lapangan masih dipengaruhi oleh ego centris masing-masing. Sehingga sering terjadi benturan kepentingan di dalam pelaksanaannya.

Hal yang lebih tragis adalah sertifikasi yang telah dikeluarkan oleh lembaga-lembaga asosiasi tersebut tersebut ternyata tidak diakui dalam tingkat regional dan internasional. Salah satu upaya yang dapat dikembangkan adalah mencoba menggalang kerjasama dengan lembaga-lembaga sejenis yang ada di manca negara, sehingga diharapkan sertifikasi yang dikeluarkan dapat dipergunakan di tingkat regional bahkan internasional. (Wibowo \& Hadihardaja, 2006)

Undang-Undang Jasa Konstruksi yang mana mengamanatkan terhadap masyarakat untuk berperan aktif terhadap pengembangan industri konstruksi hendaknya diimbangi oleh peran pemerintah sebagai pihak fasilitator aktif. Hal ini diperlukan guna menjaga kewibawaan dan independensi untuk mengurangi benturan-benturan konflik yang berkepanjangan diantara asosiasi-asosiasi perusahaan ataupun asosiasi profesional. (Wibowo \& Hadihardaja, 2006)

Sektor jasa konstruksi mempunyai peran penting bagi pencapaian sasaran pembangunan nasional termasuk penyediaan lapangan kerja. Selama delapan tahun terakhir tahun 2000-2007 jasa konstruksi mampu menyerap tenaga kerja antara 3,9 juta-4,5 juta orang per tahun atau sekitar 3,94,8\% dari total jumlah tenaga kerja.

Pengembangan jasa konstruksi mendatang harus dititikberatkan pada pengembangan kompetensi tenaga kerjanya sehingga meningkatkan kualitas produk jasa konstruksi. Undang undang No 18 Tahun 1999 tentang Jasa Konstruksi mengamanatkan tenaga ahli dan tenaga kerja bidang jasa konstruksi harus memiliki sertifikat keahlian dan atau keterampilan konstruksi. 
Lembaga Pengembangan Jasa Konstruksi (LPJK) baik di tingkat nasional maupun daerah, memainkan peran penting dalam pengembangan tenaga kerja industri konstruksi melalui pelaksanaan fungsi akreditasi asosiasi profesi dan institusi pendidikan dan pelatihan (diklat), serta registrasi tenaga kerja. Semua pekerja industri konstruksi harus mempunyai sertifikat tenaga kerja yang dikeluarkan oleh asosiasi profesi atau institusi diklat, dan kemudian wajib melakukan registrasi di LPJK.

Pembinaan tenaga kerja industri konstruksi dalam kerangka UU No. 18 Tahun 1999, tidak membahas secara khusus peran lembaga pendidikan dan pelatihan yang fungsinya sangat strategis dalam meningkatkan keahlian dan keterampilan kerja. Tanggung jawab dan mekanisme yang diperlukan untuk memperoleh sertifikat diserahkan pada asosiasi profesi. (Adi \& Wibowo, 2010)

\section{KESIMPULAN}

1. SKA dan SKT yang dikeluarkan oleh Badan sertifikasi Keahlian/BSA dan Badan Sertifikasi Ketrampilan/BSK belum dilakukan sesuai dengan prosedur yang semestinya.

2. Kompetensi SBU, SKA dan SKT berkontribusi terhadap Kegagalan Konstruksi dan Kegagalan Bangunan

Dari faktor tenaga kerja, faktor yang paling berpengaruh sebagai penyebab keterlambatan pelaksanaan proyek adalah faktor keahlian tenaga kerja

Mendorong pemerintah untuk menjadi fasilitator aktif dalam aspek pendanaan dan penyusunan kriteria akreditasi, perijinan dan sertifikasi.

Lembaga pendidikan dan pelatihan belum menjalankan fungsinya sangat strategis dalam meningkatkan keahlian dan keterampilan kerja. Tanggung jawab dan mekanisme yang diperlukan untuk memperoleh sertifikat diserahkan pada asosiasi profesi. 


\section{DAFTAR PUSTAKA}

Abduh, M., Soemardi, B.W., Wirahadikusumah, R.D, 2008, Kesenjangan Antar Kompetensi Pendidikan Tinggi dengan Kompetensi Keahlian Konstruksi Proceedings KoNTekS 2 Inovasi dalam Rekayasa Sipil dan Lingkungan, Yogyakarta 6 -7 Juni 2008 , 235 - 246

Adi, Henny Pratiwi ; Adillah, Siti Ummu 2012 Sertifikasi Tenaga Kerja Konstruksi Sebagai Unsur Pendukung Pembangunan Infrastruktur Seminar Nasional Fakultas Teknik Unissula

Adi, Henny Pratiwi ; Wibowo, M. Agung 2010 Evaluasi Kinerja Stakeholders Dalam Pembinaan Keterampilan Tenaga Kerja Konstruksi Dengan Metode Performance Prism Media Teknik Sipil, Volume X, Juli $2010 ; 106$ - 112

Ardiansyah , Dedy ; Nailul , Hasmi ; Utomo , Jati DH ; Kistiani , Frida, 2012, Kontribusi Sertifikasi SDM Konstruksi Terhadap Kegagalan Konstruksi Dan Kegagalan Bangunan Studi Kasus Provinsi Jawa Tengah Jurnal Karya Teknik Sipil 1.1 (2012): 1-10.

Asnudin, Andi 2008 Potensi Bisnis Usaha Jasa Konstruksi Di Indonesia, Jurnal IImiah "SMARTek" Fakultas Teknik Universitas Tadulako, Palu, Vol. 6, No. 4, Nopember 2008: $228-240$

Asnudin, Andi 2013 Potret Pengadaan Jasa Konstruksi Secara Elektronik Di Sulawesi Tengah. Majalah IImiah "MEKTEK” Fakultas Teknik Universitas Tadulako, Palu, Vol. 14.3

Kuncoro, Tri, 2012, Kebutuhan Bahan Uji Sertifikasi Keahlian Bangunan Pada Model Regional Model Of Standard Competency (RMCS)BANGUNAN (Jurnal Berkala Jurusan Teknik Sipil UM) 19.184 - 103

Rachmanto, D 2009, Analisa Tingkat Persepsi Dan Kepentingan Pelaksanaan Sertifikasi Tenaga Ahli Di Surabaya Studi Kasus Sertifikasi Tenaga Ahli Arsitek (IAI) Jawa Timur Prosiding Konferensi Nasional Teknik Sipil 3, UPH, Karawaci

Rahardjo, Pentadri. 1996. Komponen Penentu Mutu Bata Merah Pejal di Pasaran Kodya Semarang dan Alternatif Upaya Peningkatannya. Semarang : Politeknik Universitas Diponegoro

Siswanto, B Ismadi, 2008, Unggulan Daya Saing Arsitek Profesional Dalam Persaingan Global, Teknik Sipil dan Arsitektur 5.9 (2008).

Taufik, Ade Irawan, 2012, Pembaharuan Regulasi Jasa Konstruksi Dalam Upaya Mewujudkan Struktur Usaha Yang Kokoh, Andal, Berdaya Saing Tinggi Dan Pekerjaan Konstruksi Yang Berkualitas, Jurnal RechtsVinding, Media Pembinaan Hukum Nasional, vol 1 nomor 2 Agustus 2012 
Wibowo, M Agung ; Hadihardaja, Joetata 2006 Badan Akreditasi Nasional Industri Konstruksi Suatu Kebutuhan, Media Komunikasi Teknik Sipil, Volume 14, NO. 3, Edisi XXXVI Oktober 2006

Wiyana, Yustinus Eka 2012, Analisis Kegagalan Konstruksi Dan Bangunan Dari Perspektif Faktor Non Teknis, Wahana TEKNIK SIPIL Vol. 17 No. 1 Juni 2012 54-60

Wuryanti, Wahyu, 2010 Standardisasi Pedoman Pengukuran Produktivitas Tenaga Kerja Untuk Pekerjaan Konstruksi Bangunan Gedung Prosiding PPI, Standardisasi, 2010 Banjarmasin, 4 Agustus 2010 